\title{
Ethno-linguistic Groups during an Economic Recession: Low-income Earners in the 1990s' Finland
}

CAMILLA HÄRTULL

Department of Social Sciences, Åbo Akademi University, Vaasa, Finland JAN SAARELA

Swedish School of Social Science, University of Helsinki \& Department of Social Sciences, Åbo Akademi University, Vaasa, Finland

\begin{abstract}
Little is known about low-income earners in the Swedish-speaking community in Finland, and particularly how this ethno-linguistic group positioned itself as compared with the Finnish speakers during the severe economic recession in the 1990s. Relating to the ethno-linguistic English-speaking minority in Quebec, we set out to study whether also Swedish speakers experienced a worsening of their economic position. Using register data from 1987-1999, we find that they did not, but rather improved their relative situation as compared with the Finnish speakers, although they on average had a higher propensity for being low-income earners also after the recession. In contrast to the situation in Quebec, no unfavourable language acts or educational reforms were imposed on the Swedish speakers during the study period. We see the results as reflecting a well-functioning welfare state, in which language acts and constitutional rights have worked to protect both ethno-linguistic groups.
\end{abstract}

Keywords: low-income earners, ethno-linguistic minorities, economic recessions, Finland, Quebec

\section{Introduction}

An overall picture of the economic situation of many ethnic minority groups is that they are in a poorer position than people in the majority population (e.g. Gradín 2012; Kahanec, Zaiceva and Zimmermann 2010; Mnookin and Verbeke 2009; Semyonov and Lewin-Epstein 2009; Van Rie and Marx 2013). Swedish speakers in Southern and Western Finland, who are the focal points of this paper, and Anglophones (English speakers) in the province of Quebec in Canada, who we relate to, constitute two striking exceptions. In a historical perspective, both groups have been overrepresented in the upper part of the income distribution, and they have some notable similarities in terms of social position and constitutional rights (Albouy 2008; McRae 1997; Saarela 2004). 
Swedish speakers in Finland constitute an indigenous group that amounts to 5.5 percent of the total population of five million persons. Swedish is alongside Finnish one of the two official languages of the country, and as a consequence, Swedish speakers have equal constitutional rights as the Finnish speakers and an own parallel education system. In Quebec, the only official language is French, but Anglophones constitute an official linguistic minority in the province. As many as 7.5 percent of the population of eight million persons has English as their mother tongue, and the proportion of people who speak English as their first official language is approximately 13.5 percent (Corbeil, Chavez and Pereira 2010; Government of Canada 2014; Statistics Canada 2011). The Anglophones are guaranteed the right to use the language in the parliament and courts of law and their children are on certain conditions guaranteed the right to English education. Provincial legislation has nevertheless delimited the language rights of Anglophones and the role of their institutions.

The Swedish-speaking population of Finland has been extensively studied (Finnäs 1986; Koskinen and Martelin 2003; McRae 1997; Saarela 2006; Saarela and Finnäs 2004, 2009, 2014). Yet little is known about how they are positioned at the lower end of the income distribution as compared with people in the Finnish-speaking majority. The economic turbulent 1990s is particularly interesting, since Finland then experienced the most severe recession an industrialised nation had witnessed in modern peacetime (Jonung, Kiander and Vartia 2008). The aim with this paper is therefore to analyse if Swedish speakers and Finnish speakers differ in the probability of being low-income earners during this economically turbulent period, meaning that changes in the macroeconomic environment might have affected the ethno-linguistic groups differently. By doing so, we relate to previous research on comparisons between Anglophones and Francophones (French speakers) in Quebec.

Like Finland, also Quebec experienced a severe economic downturn in the 1990s. Many industrial jobs occupied by the Anglophones were lost in the province. The wage gap in relation to the Francophones diminished, and the Anglophones were faced with a higher relative risk of being low-income earners. Legislative changes that enforce regulations, impediments, and hindrances unevenly on ethnic subgroups can influence economic activity. Accordingly, Anglophones were affected by unfavourable educational reforms and language acts during the 1990s, and these legislative changes, together with the Francophones' increasing dominance over the provincial economy, are assumed to be the primary reasons behind their worsened relative position (Albouy 2008; Lussier 2012).

In Finland, there were not any similar legislative changes that affected the Swedish speakers during this period. This makes us suspect that the ethno-linguistic minority group in Finland did not experience a similar worsening of its relative economic position as the Anglophones in Quebec. Business cycles are indeed known to affect labour market outcomes of ethnic groups differently, and minorities in particular tend 
to suffer during economic recessions (Cummings 1987; Engemann and Wall 2010; Rosholm, Scott and Husted 2006), but the relative economic position of an ethnic group is largely associated with its specific exposure and societal position (Hoynes, Miller and Schaller 2012). If group members work in industries and occupations that are less affected by changes in the macroeconomic environment, and in case they have extent social networks, they are less vulnerable to economic downturns (e.g. Brenner and Kiefer 1981; Coleman 1988; Montgomery 1992; Shackett and Trapani 1987). Much previous research characterise Swedish speakers on these premises (e.g. Finnäs 2003; Saarela and Finnäs 2003a, 2006), albeit there exist no direct evidence about the potential causal effects. What is clear still is that the Swedish speakers were not exposed to any unfavourable educational reforms or language acts during the 1990s, which could have worsened their relative position. Hence, if the development of the Swedish speakers' relative economic position during the 1990s differs from that of the Anglophones in Quebec it is presumably because they were not exposed to any unfavourable legislation.

\section{Ethno-linguistic groups and the recession in the 1990s}

Finland was part of Sweden until 1809. During this time, and many decades thereafter, Swedish was the language of the economic, social and cultural elite, and the administrative language in the country. A common presumption about the Swedish speakers is that they are overrepresented among those well-to-do. To some extent this is true. Swedish speakers are higher educated and live longer than people in the majority population (Saarela and Finnäs 2003b, 2006, 2010).Wealth levels are on average higher among Swedish speakers than among Finnish speakers and in the Helsinki metropolitan area, the mean wage of Swedish-speaking men is higher than that of Finnish-speaking men (Saarela 2004, 2006; Saarela and Finnäs 2004). However, due to considerable regional variation, there exists no unequivocal evidence for a benign situation.

As compared with Francophones in Quebec, Anglophones are overrepresented among persons with high income (Floch and Pocock 2008), their wages have been higher (Albouy 2008), and they are higher educated and live longer (Auger et al. 2012; Lussier 2012). Anglophones controlled the economy until the 1960s in terms of being business owners, but thereafter their economic position deteriorated (Shapiro and Stelcner 1997; Vaillancourt, Lemay and Vaillancourt 2007). In the 1970s, the wage advantage of the Anglophones was notably larger in the upper part of the income distribution than in the lower part. At the end of the decade, many large multinational companies withdrew from Montreal. This led to a general fall in income in the upper deciles, which were dominated by the Anglophones. Still in the mid-1990s the average income of Anglophones was higher, largely because of higher educational levels, but the wage spread within the group had widened (Albouy 2008; Lussier 2012). In the early 2000s, the median income of Anglophones was higher and a higher proportion was found at the higher end of the income spectrum, but they also constituted a higher 
share of people in the lowest part of the income distribution (Floch and Pocock 2008; Lussier 2012). Educational reforms, language acts, and the Francophones' increasing dominance over the economy appear to be the primary reasons behind the worsened relative position of the Anglophones in Quebec (Albouy 2008).

Little is known about low-income earners in the Swedish-speaking community in Finland, and particularly about any differences as compared with Finnish speakers. The only study on this topic is concerned with social assistance receipt in a local labour market, the city of Vaasa, during the peak of the economic recession in the 1990s (Saarela 2002). It found that the probability of receiving social assistance, which is a rough proxy for low income, was notably higher among Finnish speakers than among Swedish speakers. Whether these findings can be generalised for the two ethno-linguistic groups, or whether data from a single year are representative for the whole turbulent period of the 1990s, is not clear. A central question of ours is therefore whether the relative position of the ethno-linguistic minority group in Finland has changed, like the case for the Anglophones in Quebec.

There is a notable similarity between Finland and Quebec also with respect to the extent of the 1990s' economic recession. Quebec was the province in Canada that was most severely affected by the economic downturn in the 1990s. The fall in the gross domestic product was deeper and the recovery took longer than in any other part of the country (Stevens 1996). The recession resulted in job losses in the industrial sector that traditionally had employed many Anglophones in the lower income deciles and when long-term unemployment started to increase, Quebec was the province in Canada that economically suffered most (Dubé 2004). Finland, on the other hand, was the country in Europe that was hardest hit by the 1990s' economic downturn (Kiander and Vartia 2011). Like its neighbouring country Sweden, Finland liberalised its financial markets in the mid-1980s. This induced rapid credit expansion, low rates of interest, capital imports, growing trade deficits, and asset bubbles. The sharp increase in asset prices expanded household wealth, which eventually led to a sharp rise in the real interest rate. Asset prices then started to fall and finally collapsed. The borrowers and the financial system were put under severe pressure due to negative wealth effects, output and employment decreased, and the budget deficit rose sharply (Jonung et al. 2008). Real income losses were greater than ever witnessed during any previous peacetime financial crisis, and the unemployment rate was even higher than during the great depression in the 1930s (Jonung and Hagberg 2005). The unemployment rate skyrocketed from 3.2 percent in 1990 to 16.6 percent in 1994. Thereafter it gradually decreased until 2009 (Statistics Finland 2013). Both Swedish speakers and Finnish speakers experienced elevated unemployment levels during the recession, albeit the unemployment rate of Finnish speakers was consistently higher (Figure 1). 

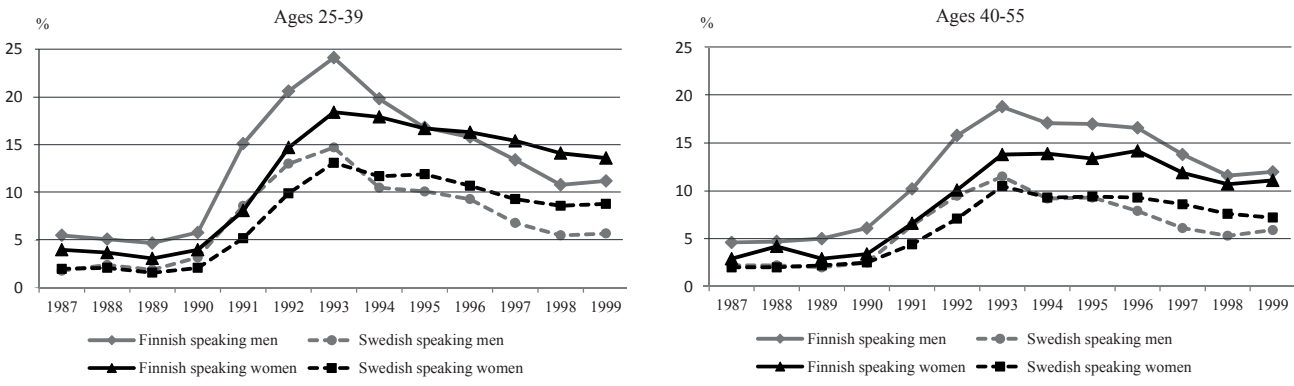

Non-metropolitan area
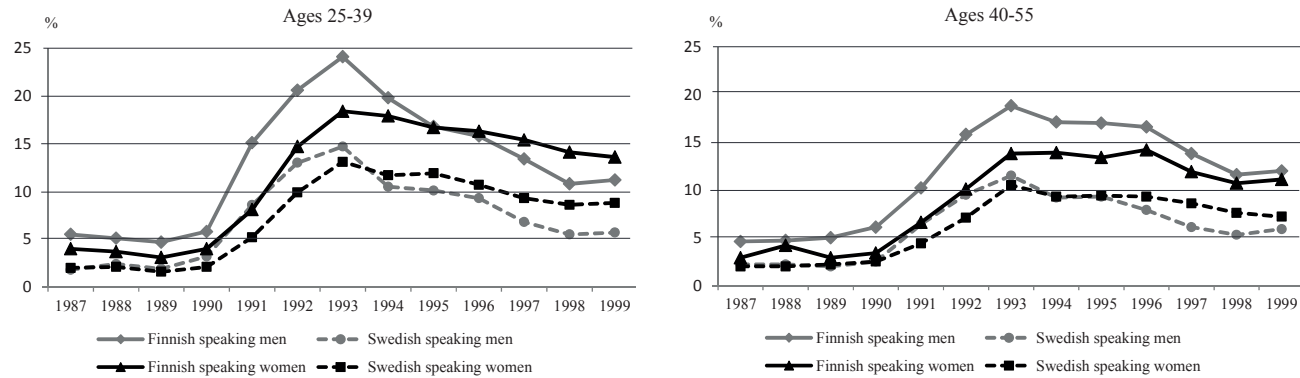

Figure 1. Unemployment rate (\%) in the metropolitan and non-metropolitan areas, 1987-1999.

Note: The description refers to Southern and Western Finland as mentioned in the data section.

The economic safety net is nevertheless much more covering in Finland than in Canada. Due to an extensive welfare system that incorporates taxable unemployment benefits related to pre-unemployment wages, there is although not a one-to-one relationship between unemployment and income. Only a thorough empirical inquiry can therefore scrutinize the question of whether the two ethno-linguistic groups in Finland were differently affected in terms of being low-income earners during the 1990s' economic downturn. 


\section{Data}

The data are based on Statistics Finland's employment statistics file entitled 'Työssäkäyntitilasto'. It contains basic information at the annual level about variables related to each individual's socioeconomic, demographic and labour market position, including income, for each year of the period 1987-1999. Since each person in the Finnish population register is uniquely identified by mother tongue, we can separate Swedish speakers and Finnish speakers. The data used here consist of a 20 percent sample of all Swedish speakers and a five percent sample of all Finnish speakers, who were living in any of the provinces in Southern and Western Finland that had both Swedish-speaking and Finnish-speaking settlement at any of the years studied. The study is consequently concerned with people who live in the same geographic area, in which 95 percent of all Swedish speakers in Finland live. This demarcation limits the scope for broader regional income variation. Municipalities with Finnish-speaking population only, and the Åland Islands that constitute an autonomous Swedish-speaking area, are excluded from analyses. The analysed number of individuals is on average 49,200 per year.

To focus on prime working ages, we have restricted the data to persons aged 25-55 years. All analyses are stratified by sex, age group, and region. Age group separates people aged 25-39 years and those aged 40-55 years. Region separates the metropolitan area, consisting of the municipalities Helsinki, Espoo, Vantaa and Kauniainen, and the non-metropolitan area, which consists of all the other municipalities. The stratification is because initial analyses revealed that the ethno-linguistic difference in low-income propensity varied across these categories. Alternative categorisations and interactions were initially tried, but the approach taken here fit the data best and the results are conveniently illustrated graphically.

In Finland, there exists no officially established cut-off point for being a low-income recipient or living in poverty. Based on the recommendation of Eurostat, Statistics Finland although classifies persons as low-income recipients if they live in households whose disposable income per consumption unit is below 60 percent of the median equivalent income of all households. Since the data used here is at the individual and not at the household level, we cannot explicitly utilise this threshold. We therefore categorise people as being low-income earners if they have an annual taxable income below 10,000 euro in 2011 year's prices. Taxable income refers to all earnings from employment and self-employment, capital income, and taxable payments in kind. Based on this categorisation, the proportion of low-income earners in the data is 10-17 percent, depending on the observation year and subgroup studied. This is only slightly higher than the proportion of low-income recipients according to Statistics Finland's definition (Statistics Finland, 2008). Shifting the threshold some thousand euros below or above the 10,000 level has only marginal effects on the results. 
Control variables used are education, age, family situation, municipality of residence, and labour market status, which all are correlated with income (Asplund and Maliranta 2006; Idman 2012; Knuuti 2013; Myrskylä 2010; Salonen 2009; Statistics Finland 2005). Education refers to the level of education combined with the field of education. The former consists of six categories ranging from basic education to higher-degree tertiary level, and the latter of eight different categories. Age is used as a categorical variable with five-year intervals. Family situation distinguishes singles, sole supporters, couples without children, and couples with children. Municipality of residence has 48 different categories. Labour market status refers to whether a person is employed, unemployed, or outside the labour market.

For the sake of simplicity, and because the control variables are merely used to account for potential distributional differences across the two ethno-linguistic groups with respect to characteristics generally associated with income, estimates of the control variables are not displayed. In focus is the estimate for ethno-linguistic affiliation, which reflects the difference in the propensity to be a low-income earner between Swedish speakers and Finnish speakers, and particularly if it has changed over time and in relation to the 1990s' economic crisis.

\section{Results}

We begin by providing the share of low-income earners among Swedish speakers and Finnish speakers, respectively, for each year and stratified by sex, age group and region. This is the upper graphs (A) in each of the Figures 2-5, where the left-hand part refers to men and the right-hand part to women. The subsequent graphs (B) give the unadjusted odds ratio for each year, that is, the ratio of the share of low-income earners among the Swedish speakers and the share of low-income earners among the Finnish speakers. Graphs (C) refer to odds ratios that adjust for education, age, family situation, and municipality of residence. Graphs (D) additionally accounts for labour market status.

We want to account for as much distributional differences across the two ethno-linguistic groups as possible, and therefore estimate separate regressions by calendar year, sex, age group (25-39 and 40-55 years), and region (metropolitan and non-metropolitan) with the sets of control variables as mentioned above. The results consequently refer to 104 different regressions for each of the Graphs (B), (C), and (D). In general, the set of parameters for each control variable improves the fit of the model estimated, albeit all single parameters are not statistically significant. Alternative categorisations of the control variables had no practical influence on the estimates for the ethno-linguistic difference, however. 
Men

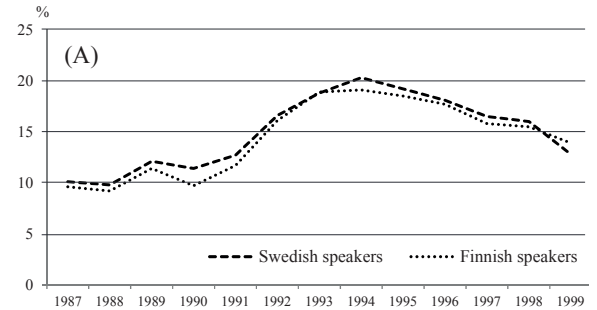

Odds Ratio

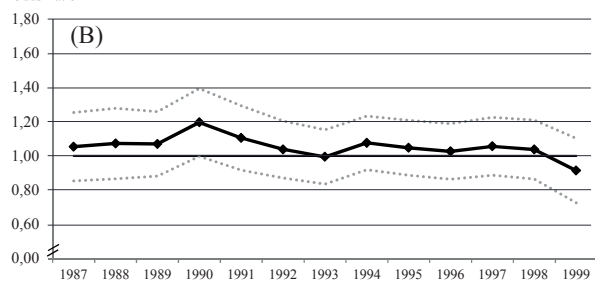

Odds Ratio

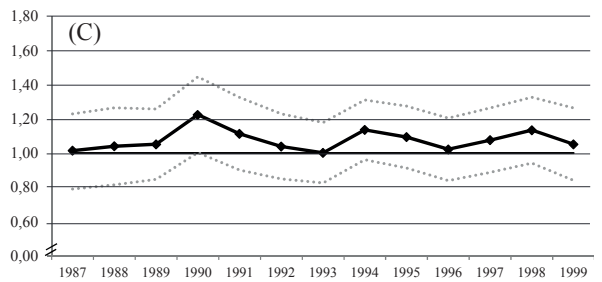

Odds Ratio

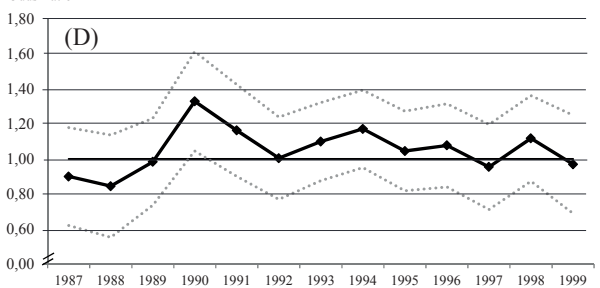

Women

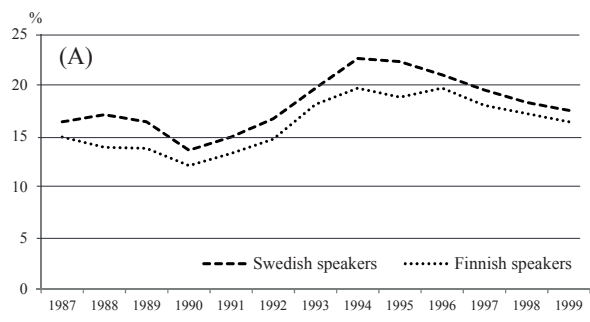

Odds Ratio

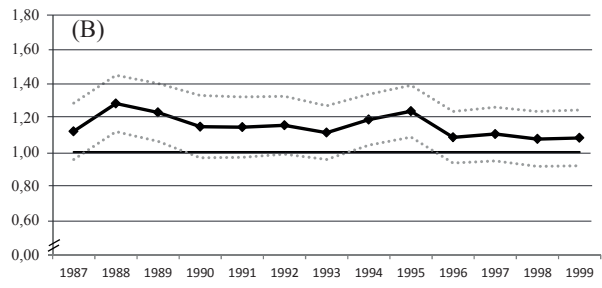

Odds Ratio

\begin{tabular}{l}
$1,80 \quad(\mathrm{C})$ \\
\hline
\end{tabular}

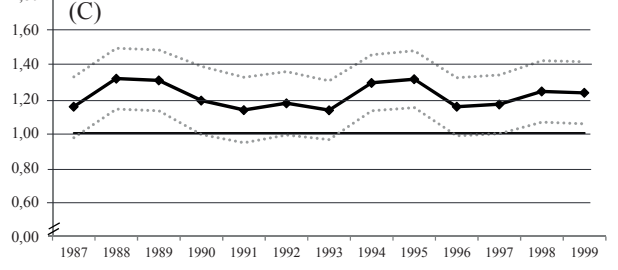

Odds Ratio

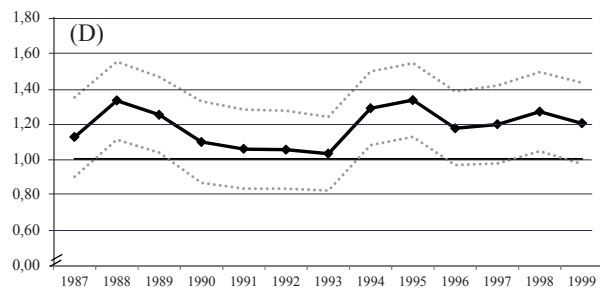

Figure 2. Percentage low-income earners in 1987-1999 and odds ratio of being a low-income earner between Swedish speakers and Finnish speakers, men and women aged 25-39 years in the metropolitan area.

Notes: (A) Percentage low-income earners by ethno-linguistic group. (B) Unadjusted odds ratio of being a low-income earner between Swedish speakers and Finnish speakers. (C) Odds ratio of being a low-income earner between Swedish speakers and Finnish speakers, adjusted for education, age, family situation, and municipality of residence. (D) Odds ratio of being a low-income earner between Swedish speakers and Finnish speakers, additionally adjusted for labour market status. 
Men

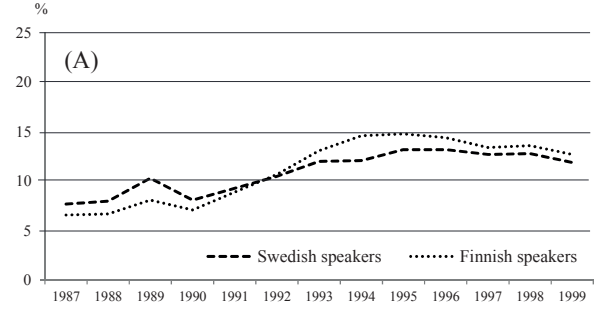

Odds Ratio

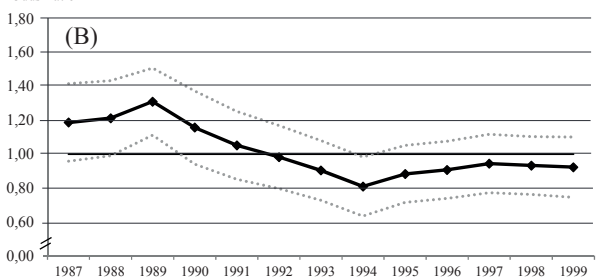

Odds Ratio

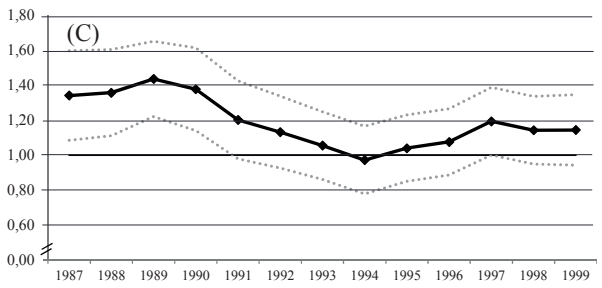
Odds Ratio

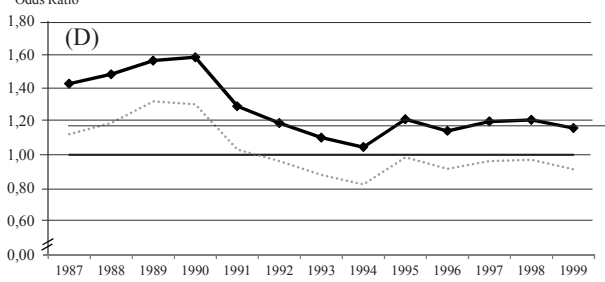

Women

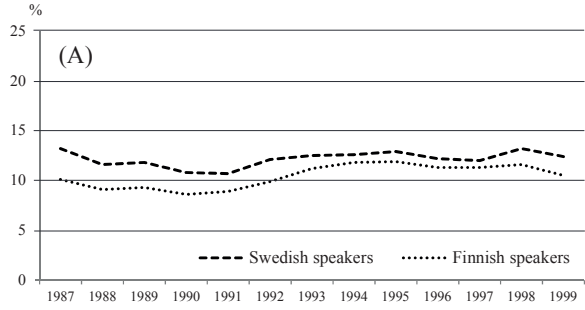

Odds Ratio

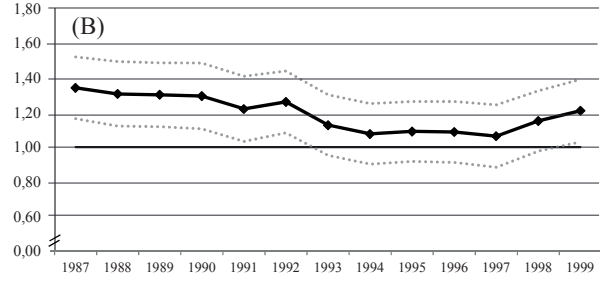

Odds Ratio

1,80

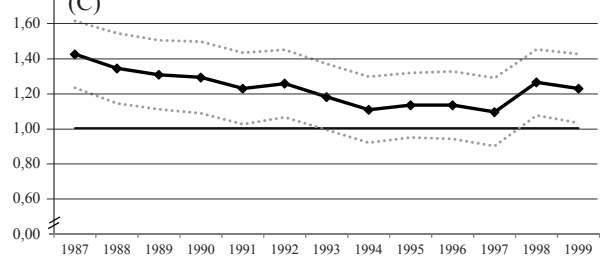

Odds Ratio

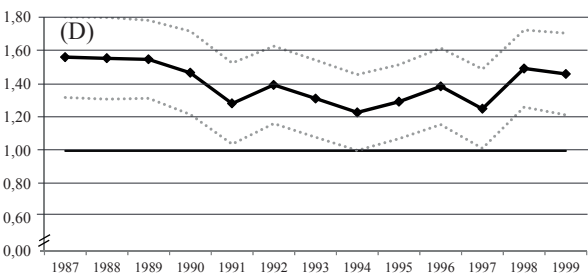

Figure 3. Percentage low-income earners in 1987-1999 and odds ratio of being a low-income earner between Swedish speakers and Finnish speakers, men and women aged 40-55 years in the metropolitan area.

Notes: (A) Percentage low-income earners by ethno-linguistic group. (B) Unadjusted odds ratio of being a low-income earner between Swedish speakers and Finnish speakers. (C) Odds ratio of being a low-income earner between Swedish speakers and Finnish speakers, adjusted for education, age, family situation, and municipality of residence. (D) Odds ratio of being a low-income earner between Swedish speakers and Finnish speakers, additionally adjusted for labour market status. 
Men

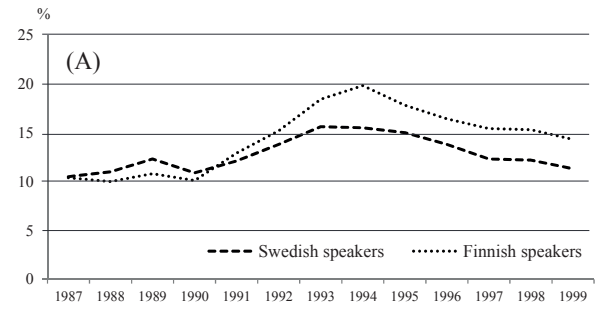

Odds Ratio

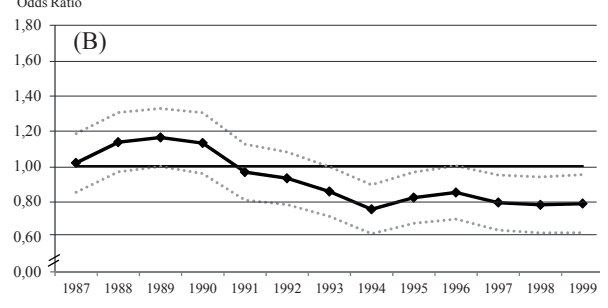

Odds Ratio

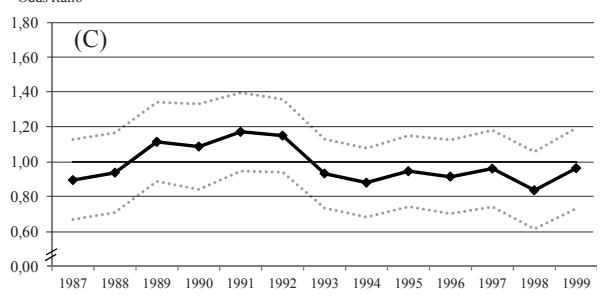

Odds Ratio

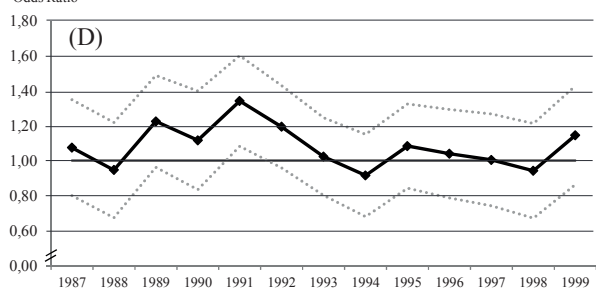

Women

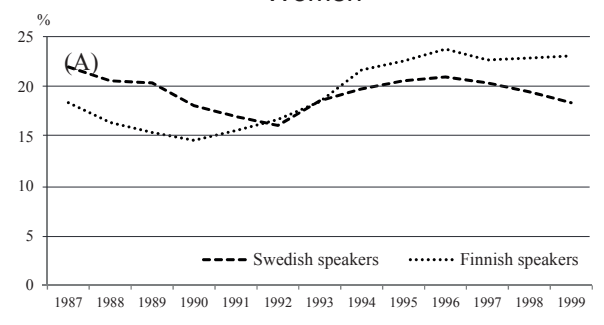

Odds Ratio

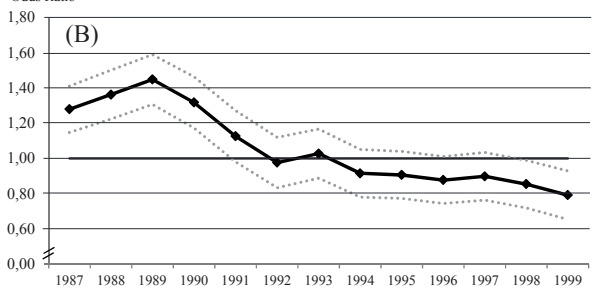

Odds Ratio

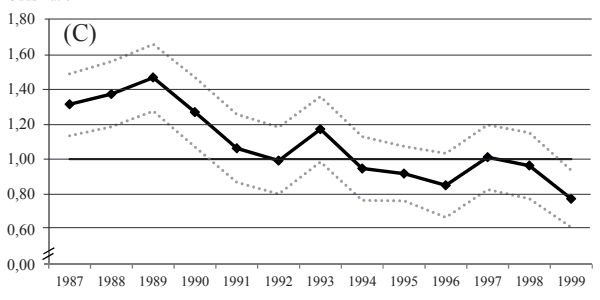

Odds Ratio

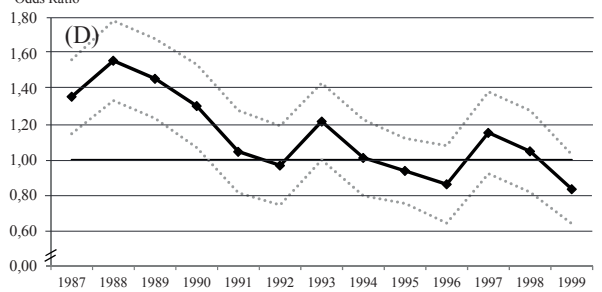

Figure 4. Percentage low-income earners in 1987-1999 and odds ratio of being a low-income earner between Swedish speakers and Finnish speakers, men and women aged 25-39 years in the non-metropolitan area.

Notes: (A) Percentage low-income earners by ethno-linguistic group. (B) Unadjusted odds ratio of being a low-income earner between Swedish speakers and Finnish speakers. (C) Odds ratio of being a low-income earner between Swedish speakers and Finnish speakers, adjusted for education, age, family situation, and municipality of residence. (D) Odds ratio of being a low-income earner between Swedish speakers and Finnish speakers, additionally adjusted for labour market status. 
Men

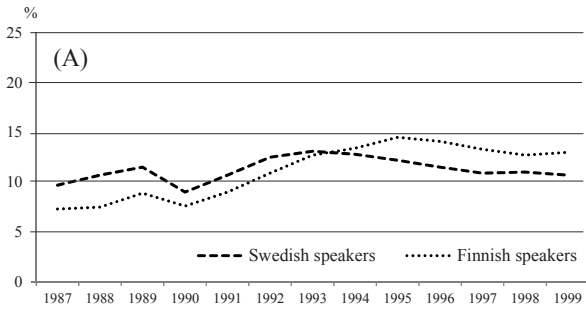

Odds Ratio

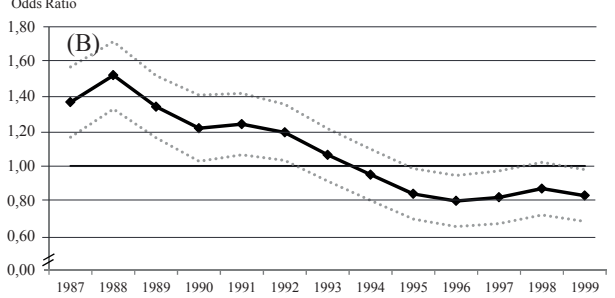

Ratio

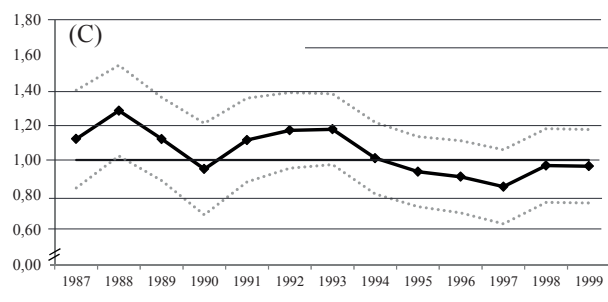

Odds Ratio

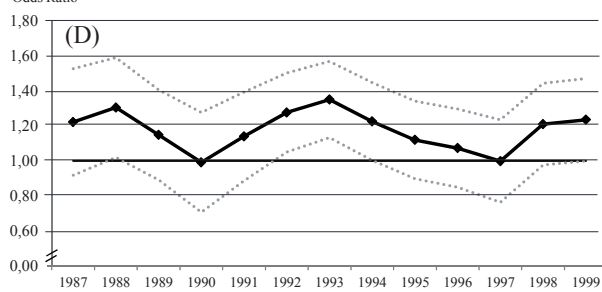

Women

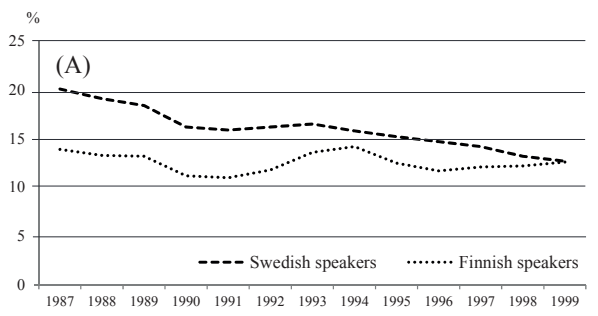

Odds Ratio

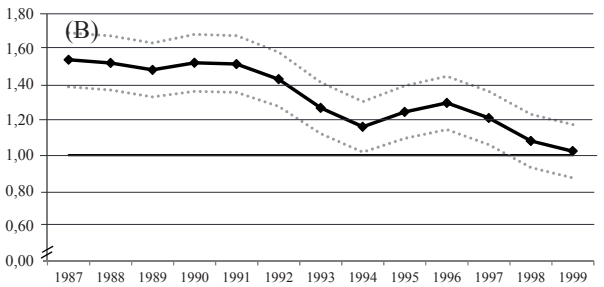

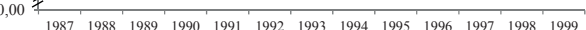

Odds Ratio
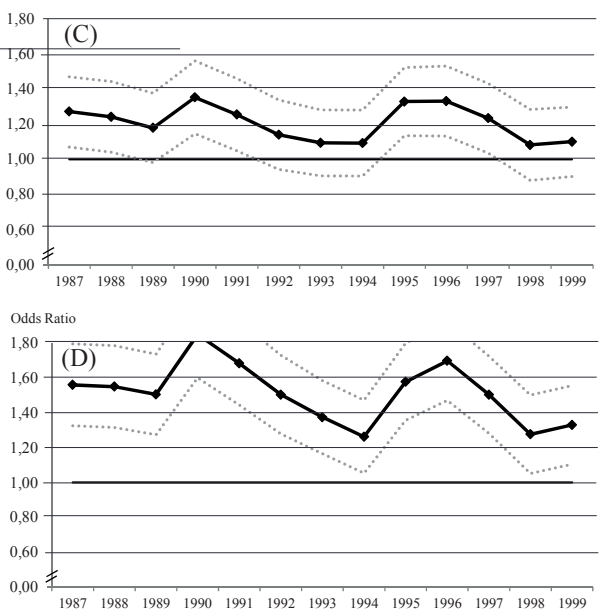

Figure 5. Percentage low-income earners in 1987-1999 and odds ratio of being a low-income earner between Swedish speakers and Finnish speakers, men and women aged $40-55$ years in the non-metropolitan area.

Notes: (A) Percentage low-income earners by ethno-linguistic group. (B) Unadjusted odds ratio of being a low-income earner between Swedish speakers and Finnish speakers. (C) Odds ratio of being a low-income earner between Swedish speakers and Finnish speakers, adjusted for education, age, family situation, and municipality of residence. (D) Odds ratio of being a low-income earner between Swedish speakers and Finnish speakers, additionally adjusted for labour market status.

The figures show that during the 1990s' economic recession, the likelihood of being a low-income earner increased considerably in all male subgroups studied. In the metropolitan area, for instance, approximately ten percent of the male population 
aged 25-39 years had a taxable income below 10,000 euro in the late 1980s. By the mid-1990s, this share had risen to almost 20 percent, where after it dropped to approximately 13 percent at the end of the decade. For women, a similar development can be seen only for the younger group, albeit they are at a higher level than men. The share of low-income earners in the other subgroups of women does not seem closely related to the economic downturn.

Variation over time is highly similar for Swedish speakers and Finnish speakers, irrespective of the subgroup studied. However, there is a trend which suggests that the relative position of Swedish speakers as compared with Finnish speakers improved during the 1990s. The perhaps most striking example on this account is older men in the non-metropolitan area. In 1987, the odds ratio of being a low-income earner was almost 40 percent higher for Swedish speakers as compared with Finnish speakers, whereas in 1999 it had decreased and was approximately 20 percent lower. There is a similar but less marked trend in the other subgroups, except perhaps for younger men and women in the metropolitan area, among whom Swedish speakers tend to be at slightly higher levels than Finnish speakers irrespective of the year studied.

When control variables additionally are included not much happens with the ethnolinguistic difference. The estimates are remarkably stable when unadjusted and adjusted odds ratios are being compared. Even when labour market status is included in graphs (D), conclusions are the same. Differences in the propensity to be a low-income earner between Swedish speakers and Finnish speakers cannot consequently to any greater extent be attributed to standard human capital factors. It is also evident that Swedish speakers in Finland did not experience a worsened relative position, but rather a relative improvement as compared with the Finnish speakers. It is not obvious that the change can be related to the economic recession, however, as the improved position appears to be associated with a general trend that started before the recession and continued after it.

Yet it needs to be stressed that, although the trend was in favour of the Swedish speakers, they have on average had a higher propensity for being low-income earners than Finnish speakers. This finding is particularly marked for the older working-aged group in the metropolitan area, for whom the adjusted odds ratio for being a low-income earner is $10-55$ percent higher as compared with Finnish speakers. 


\section{Discussion}

The aim of this paper was to study ethno-linguistic differences in the propensity to be a low-income earner in Finland around the time of the 1990s' economic recession, relating to previous research on ethno-linguistic groups in Quebec. The economic history and social position of the Swedish speakers in Finland has been, if not analogous, at least highly comparable to that of Anglophones in Quebec.

In the 1990s, the relative position of Anglophones in Quebec deteriorated and they were faced with a higher risk of being low-income earners as compared with the Francophones. Many industrial jobs occupied by the Anglophones were lost in the region. Educational reforms and language acts additionally worsened their relative position. In Finland, no similar changes in legislation were undertaken during this time. We therefore set out to study whether also Swedish speakers experienced a similar worsening of their economic position as the Anglophones in Quebec, and whether it might be associated with the 1990s' economic downturn.

In contrast with the evidence for Anglophones in Quebec, we find that Swedish speakers in Finland did not experience a worsened relative position during the 1990s, but rather an improvement as compared with the Finnish speakers. The underlying reason might be the same as in Quebec, however, since a higher proportion of Finnish speakers than Swedish speakers have of tradition worked in manufacturing and other industries that are sensitive to fluctuations in the business cycle (Finnäs 2003; Saarela and Finnäs 2006). In the wake of the 1990s' economic recession, many such jobs were lost and there were many structural changes in the labour market. The size of the public sector shrank, the number of blue-collar jobs diminished, the structure of the labour force altered, and the number of temporary job contracts increased (Lehto and Sutela 2008). It is plausible that these changes affected Finnish speakers to a greater extent than Swedish speakers. In the metropolitan area, Finnish speakers tend to be more alike Swedish speakers on occupational distribution than they are elsewhere (Finnäs 2003). The ethno-linguistic difference in the probability of being a low-income earner should consequently be less associated with macroeconomic fluctuations in the metropolitan area than elsewhere, and this is also what we see in the younger age group studied. Yet since we control for each person's labour market position, variation in unemployment probability is presumably not the sole reason behind the ethno-linguistic variation observed. Latent differences in terms of language skills, social networks and local-level factors might therefore also have played a role.

In light of the evidence from Canada and other countries (e.g. Blackaby et al. 2006; Drinkwater and O'Leary 1997; Rendon 2007), the role of educational reforms and language acts seem crucial in understanding the relative position of ethno-linguistic minorities in society and on the labour market. Accordingly, the absence of any unfavourable changes imposed on the Swedish speakers on this concern appears to have 
helped them in promoting their relative position during the course of the 1990s, and hence making the Finnish speakers equally vulnerable to changes in the macroeconomic environment during this turbulent decade. At the end of the study period, the two ethno-linguistic groups displayed no large difference in the probability of being low-income earners. We see these results as reflecting a well-functioning welfare state, in which language acts and constitutional rights have worked to protect both ethno-linguistic groups.

\section{Acknowledgement}

The main author would like to thank Högskolestiftelsen i Österbotten for financial support for her doctoral studies.

\section{References}

Albouy, D. (2008). The wage gap between Francophones and Anglophones: A Canadian perspective, 1970-2000. Canadian Journal of Economics/Revue canadienne d'Economique 41(4), 1,211-38.

Asplund, R. \& Maliranta, M. (2006). Koulutuksen taloudelliset vaikutukset [The impact of education on economy]. (Sitran raportteja 60). Helsinki: Sitra.

Auger, N., Harper, S., Barry, A. D., Trempe, N. \& Daniel, M. (2012). Life expectancy gap between the Francophone majority and Anglophone minority of a Canadian population. European Journal of Epidemiology 27(1), 27-38.

Blackaby, D., Latreille, P., Murphy, P., O’Leary, N. \& Sloane, P. (2006). The Welsh language and labour market inactivity. Report for the Economic Research Unit, Welsh Assembly Government. University of Wales Swansea and WELMERC.

Brenner, R. \& Kiefer, N. M. (1981). The economics of the diaspora: Discrimination and occupational structure. Economic Development and Cultural Change 29(3), 517-33.

Coleman, J. (1988). Social capital in the creation of human capital. American Journal of Sociology 94, 95-120.

Corbeil, J-P., Chavez, B. \& Pereira, D. (2010). Portrait of official-language minorities in Canada - Anglophones in Quebec. (Statistics Canada - Catalogue no. 89-642X). Ottawa: Statistics Canada. http://www.statcan.gc.ca/pub/89-642-x/89-642x2010002-eng.pdf

Cummings, S. (1987). Vulnerability to the effects of Recession: Minority and female workers. Social Forces 65(3), 834-57.

Drinkwater, S. J. \& O’Leary, N. C. (1997). Unemployment in Wales: Does language matter? Regional Studies 31(6), 583-91.

Dubé, V. (2004). Sidelined in the labour market. Perspectives on labour and income 5(4), 25-34.

Engemann, K. M. \& Wall, H. J. (2010). The Effects of Recessions Across Demographic 
Groups. Federal Reserve Bank of St. Louis Review 92(1), 1-26.

Finnäs, F. (1986). Den finlandssvenska befolkningsutvecklingen 1950-1980: En analys av en språkgrupps demografiska utveckling och effekten av blandäktenskap [An analysis of the demographic development of a language group and the effect of mixed marriages]. Helsinki: Svenska litteratursällskapet i Finland.

---. 2003. The Swedish-speaking population on the Finnish labor market. Yearbook of Population Research in Finland, 39, 91-101.

Floch, W. \& Pocock, J. (2008). The socio-economic status of English-speaking: Those who left and those who stayed. In R.Y. Bourhis (Ed.) The vitality of the Englishspeaking communities of Quebec: From community decline to revival. Montreal, Quebec: CEETUM, Université de Montréal.

Government of Canada (2014). Department of Justice. Constitution Acts, 1867 to 1982. http://laws-lois.justice.gc.ca/PDF/CONST E.pdf

Gradín, C. (2012). Poverty among minorities in the United States: Explaining the racial poverty gap for Blacks and Latinos. Applied Economics 44(29), 3, 793-804.

Hoynes, H. W., Miller, D. L. \& Schaller, J. (2012). Who suffers during recessions? Journal of Economic Perspectives 26(3), 27-48.

Idman, M. (2012). Sukupolvien väliset palkkaerot ovat vähäisiä [The intergenerational earnings disparities are small]. Hyvinvointikatsaus, 1, 25-9. Tilastokeskus.

Jonung, L. \& Hagberg, T. (2005). How costly was the crisis of the 1990s? A comparative analysis of the deepest crises in Finland and Sweden over the last 130 years. European Commission Economic Papers, No 224. Brussels: European Commission.

Jonung, L., Kiander, J. \& Vartia, P. (2008). The great financial crisis in Finland and Sweden: The dynamics of boom, bust and recovery, 1985-2000. European Commission Economic Papers, No 350. Brussels: European Commission.

Kahanec, M., Zaiceva, A. \& Zimmermann K. F. (2010). Ethnic minorities in the European Union: An overview. IZA Discussion Papers, No. 5397, IZA, Bonn.

Kiander, J. \& Vartia, P. (2011). Lessons from the crisis in Finland and Sweden in the 1990s. Empirica 38(1), 53-69.

Knuuti, J. (2013). Nouseeko palkka eläkeikään saakka? Kohorttianalyysi ikäpalkkaprofiileista ja niiden muutoksista 53-65-vuotiailla [Does wage rise until pension age? A cohort analysis of age-wage profiles and their changes among people aged 53-65-years]. Yhteiskuntapolitiikka 78 (2), 125-37.

Koskinen, S. \& Martelin, T. (2003). Why is mortality low among the Swedish-speaking minority in Finland? Yearbook of Population Research in Finland, 39, 15-31.

Lehto, A-M. \& Sutela, H. (2008). Työolojen kolme vuosikymmentä. Työolotutkimusten tuloksia 1977-2008 [Three decades of working conditions. Results of working conditions studies1977-2008]. Helsinki: Tilastokeskus.

Lussier, M-H. (2012) The socioeconomic status of Anglophones in Quebec. Publication no 1494. Montreal: Institut national de santé publique Quebec.

McRae, K. D. (1997). Conflict and compromise in multilingual societies: Finland. Waterloo, Ontario: Wilfred Lauries University Press.

Mnookin, R. \& Verbeke, A. (2009). Persistent nonviolent conflict with no reconciliation: The Flemish and Walloons in Belgium. Law and Contemporary Problems 72(2), 151-86. 
Montgomery, J. D. (1992). Job search and network composition: Implications of the strength-of-weak-ties hypothesis. American Sociological Review 57(5), 586-96.

Myrskylä, P. (2010). Taantuma ja työttömyys [Recession and unemployment]. (Työ- ja elinkeinoministeriön julkaisuja. Työ ja yrittäjyys. 57/2010). Työ- ja elinkeinoministeriö.

Rendon, S. (2007). The Catalan premium: Language and employment in Catalonia. Journal of Population Economics 20(3), 669-86.

Rosholm, M., Scott, K. \& Husted, L. (2006). The times they are a-changin': Declining immigrant employment opportunities in Scandinavia. International Migration Review 40(2), 318-47.

Saarela, J. (2002). Språkgruppsskillnader i utkomststödstagande [Language group differences in social assistance receipt]. Ekonomiska Samfundets Tidskrift 55(2), 89-97.

---. 2004. De förmögna finlandssvenskarna? [The wealthy Swedish speakers?] Janus 12(1), 80-96.

---. 2006. Wealth in Two Ethnic Groups: The Role of Internal Migration Background. Finnish Yearbook of Population Research 42, 43-64.

Saarela, J. \& Finnäs, F. (2003a). Unemployment and native language: The Finnish case. Journal of Socio-Economics 32(1), 59-80.

--- . 2003b. Social background and education of Swedish and Finnish speakers in Finland. European Journal of Education 38(4), 445-56.

---. 2004. Interethnic wage variation in the Helsinki area. Finnish Economic Papers $17(1), 35-48$.

---. 2006. Can the low unemployment rate of Swedish speakers in Finland be attributed to structural factors? Journal of Socio-Economics 35(3), 498-513.

---. 2009. Geographic ancestry and mortality from ischemic heart disease: Evidence from the Finnish population register. Population Review 48(1), 64-82.

---. 2010. Mortality variation by birth region and ethnicity: An illustration based on the Finnish population register. Human Biology 82(1), 1-15.

---. 2014. Transitions within and from ethno-linguistically mixed and endogamous first unions in Finland. Acta Sociologica 57(1), 77-92.

Salonen, J. (2009). Palkansaajien ansiot ja eläkkeet. Yksityisen ja julkisen sektorin palkansaajan ansiokehitys 1964-2004 [Incomes and pensions of wage earners. Income development of wage earners in the private and public sector1964-2004]. (Eläketurvakeskuksen keskustelualoitteita 2009:3). Helsinki: Eläketurvakeskus.

Shackett, J. R. \& Trapani, J. M. (1987). Earnings differentials and market structure. Journal of Human Resources 22(4), 518-31.

Semyonov, M. \& Lewin-Epstein, N. (2009). The declining racial earnings' gap in United States: Multi-level analysis of males' earnings, 1960-2000. Social Science Research 38(2), 296-311.

Shapiro, D. M. \& Stelcner, M. (1997). Language and earnings in Quebec: Trends over twenty years, 1970-1990. Canadian Public Policy / Analyse de Politiques 23(2), $115-40$. 
Statistics Canada. (2011). Census of Canada, 2011 Census Profile. http://www12. statcan.gc.ca/census-recensement/index-eng.cfm [accessed 18 February 2014].

Statistics Finland. (2005). Tulonjaon kokonaistilasto [verkkojulkaisu]. ISSN=1797-3279. Kotitalouksien ekvivalentti käytettävissä oleva rahatulo keskimäärin seutukunnittain vuosina 1995-2005. Vuoden 2005 rahassa [The average equivalised disposable household income by economic region 1995-2005. In 2005 year's prices]. Helsinki: Tilastokeskus http://stat.fi/til/tjkt/2005/tjkt 2005 2006-12-15 tau_004.html [accessed 11 February 2014].

---. 2008. Tulonjakotilasto [verkkojulkaisu]. ISSN=1795-8121. Pienituloisuus ikäryhmittäin ja lapsiköyhyys [Low-income earners by age group and child poverty]. Helsinki: Tilastokeskus http://www.stat.fi/til/tit/2008/01/tjt_2008_01_2010-0126_kat_004_fi.html [accessed 24 January 2014].

---. 2013. Labour market. Population by activity. http://www.stat.fi/tup/suoluk/ suoluk tyoelama en.html [accessed 24 January 2014].

Stevens, S. A. (1996). The changing structure of the Quebec economy. American Review of Canadian Studies 26(4), 523-58.

Vaillancourt, F., Lemay, D. \& Vaillancourt, L. (2007). Laggards no more: The changed socioeconomic status of Francophones in Quebec. C.D. Howe Institute Backgrounder, 103.

Van Rie, T. \& Marx, I. (2013). Growing inequalities and their impacts in Belgium. (Country report for Belgium: March 2013). European Commission. http://gini-research.org/system/uploads/444/original/Belgium.pdf?1370090423 [accessed 9 September 2013]. 